\title{
Data Element Relationship
}

National Cancer Institute

\section{Source}

National Cancer Institute. Data Element Relationship. NCI Thesaurus. Code C42644.

The affiliation between two occurrences of Data Elements. 